\title{
Research Paper: Assessment of the Social Impacts of Sewage Treatment Plant on Rural Quality of Life: A Case Study of Parkandabad Peripheral Villages Around Mashhad
}

\author{
Aliakbar Anabestani ${ }^{* *}$, Aboulfazl Zareie
}

1. Associate Professor, Department of Geography, Faculty of Letters and Humanities, Ferdowsi University of Mashhad, Mashhad, Iran.

2. PhD Student, Department of Geography, Faculty of Letters and Humanities, Ferdowsi University of Mashhad, Mashhad, Iran.

\begin{tabular}{|c|c|}
\hline $\begin{array}{l}\text { Use your device to scan } \\
\text { and read the article online }\end{array}$ & Chtation: Anabestani, A., \& Zareie, A. (2017). Assessment of the Social Impacts of Sewage Treatment Plant on Rural Quality \\
\hline 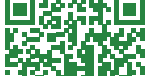 & $\begin{array}{l}\text { of Life: A Case Study of Parkandabad Peripheral Villages Around Mashhad. Journal of Sustainable Rural Development, 1(2), } \\
\text { 149-160. https://doi.org/10.29252/jsrd.01.02.149 }\end{array}$ \\
\hline arparis & doi : https://doi.org/10.29252/jsrd.01.02.149 \\
\hline
\end{tabular}

Article info:

Received: 05 Apr. 2017

Accepted: 20 Aug. 2017

Keywords:

Social impact assessment, Parkandabad sewage treatment plant, One-sample t test, Finsterbusch 12 indices

\section{ABSTRACT}

Purpose: Assessment of social impacts of large-scale developmental projects is one of the major issues in their planning and implementation. In this regard, this study investigates the social impacts of the Parkandabad sewage treatment project around Mashhad City, Iran.

Methods: For this purpose, Finsterbusch 12 indices with 43 elements were used. In the next step, 1-sample $t$ test with a standard score of 3 (as the acceptable standard level) was used at a significant level less than 0.05 .

Results: The results showed that the health and safety indexes with an average of 2.11 and aesthetics with 2.47 are in an inappropriate state, and should be considered because they are directly related to the body and mental state of humans. Some indicators (noise, facilities, communities, and utilization) were acceptable, as long as their status be improved. Several indicators (population, employment, structure, leisure, and reaction) appear to be in relatively favorable status, but this situation is due to various factors, including economic poverty in the region.

Conclusion: Finally, the desirable condition of the spatial displacement index and the change of pace of life with the average of 5.19 seems to indicate a proper living conditions, but it is not the real case. This issue is proved by a high standard deviation among respondents; i.e. inappropriate financial conditions prevent population migration and as soon as the economic condition changes, they do not stay in the current location anymore. Based on the total points of the indexes, it became clear that the Frisian village has the worst condition and Khin-e Arab the best status. 


\section{Introduction}

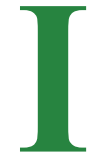

n today societies, sustainable social development is the main objective. One way to realize this objective is to establish a proper relationship between industrial projects and local community. In other words, if the proper interaction between the industry and local community is established so that the local people accept and contribute to the project, it can create new jobs and development opportunities in the region. Thus, assessment of the social impacts of projects can be very useful (Salehi, Mohammadi, Mir Mohammad Tabar Divkolai, \& Saradipour,, 2013:42) to better achieve the objectives of the projects and provide a more sustainable basis for social development (Talebian \& Omarani Majd, 2007:121).

Development despite its positive effects invariably has direct and indirect negative impacts on the society and the environment, and if the negative impacts are not anticipated, the outcomes will be dire. To improve the quality of the environment and preserving the natural and human resources, developmental plans in many countries are based on the principles of sustainable development. Therefore, in the late 1960s, assessment of social impacts of development projects was considered significant in the world and the inevitable effects of projects on the welfare, community health and ecosystem were studied. Today, studies on the social and environmental impacts of plans and projects are considered very important assets for decision making by authorities (Becker \& Wankley, 2008:17-18). These efforts have forced developing countries to examine their environmental activities more responsibly in the last two decades and try to minimize environmental damages with proper management (Alshuwaikhat, 2005:307).

In the Middle East, water and its management have always been influential in the society and economy of the countries. Today, the main challenge for the communities within this area is to provide water for various sectors. In recent decades, most countries, including Iran, have invested heavily in the water sector to reduce waterlogging and prevent water crises (Shayan et al., 2009:20). On the other hand, in recent years, due to growth in population, urbanization, industry, and agriculture, per-capita consumption of water and consequently, sewage production has increased dramatically. For this reason, the managers of the country's water and wastewater industry have more and more sought after the use of refined sewage as a sustainable water source. The use of sewage treatment plants in agriculture and industry has many benefits, such as providing a cheap and permanent supply of water, reducing waste costs, releasing part of good water quality for other uses, and reducing the environmental impacts of wastewater disposal into water resources (Mehrvaran, Ansari, Beheshti, \& Esmaieli, 2015:440). In this regard, the construction of the Parkandabad sewage treatment plant in Mashhad was started in 1996 and operated in 1998. The Engineering Department of the Isfahan University of Technology designed this treatment plant and Sarab Mashhad consultant Company constructed it. Parkandabad refinery is located on the southern edge of the Kasfrud River season, $10 \mathrm{~km}$ northwest of Mashhad, with a capacity of $15000 \mathrm{~m}^{3}$ per day; the treatment process uses the aerated lagoon sewage treatment system.

Two aeration lagoons, two basins and a pond are the main units of Parkandabad plant, which is responsible for the treatment of sewage in western urban areas of Mashhad. After removing up to $95 \%$ of wastewater, the treated water is used for agriculture (Mehrvaran, et al., 2015:441). The entrance of Parkandabad wastewater treatment plant was part of Mashhad sanitary wastewater and industrial wastewater units located along the way of Mashhad to Ghouchan and Tous Industrial Town (Mohammadyari \& Balader, 2008:37). Despite these benefits, the harmful environmental, economic and social effects of these projects, especially for the local community and surrounding areas should not be ignored (Asselin and Parkins, 2009:495; Vanclay, 2002:208). As the most research studies used to investigate the economic and environmental impacts of these projects (Karami, Karami, Buys, \& Drogemuller, 2017:25), we decided to assess the social impacts of Parkandabad sewage treatment plant, on the local community.

\section{Literature Review}

Social impacts manifest themselves in the changes in communities and cultures (Basa, 2007:8), and their assessment methods are used to study these outcomes. Social impact assessment methods have been developed for the first time in the 1970s under the National Environmental Protection Act and Environmental Impact Assessment Methods in the United States (Asselin \& Parkins, 2009:484). However, its guidelines and principles were formulated in 1994 (Tang, Wong, \& Lau, 2008:65). In recent decades, the scope of social impact assessment studies and the methods used in development projects on people and their livelihoods have been expanded (Esteves, Franks, \& Vanclay, 2012:34; Karami et al., 2017:25). Table 1 presents some of these studies in recent years. 
Table 1. Literature review in social impact assessment studies

\begin{tabular}{|c|c|}
\hline Research & Results \\
\hline $\begin{array}{l}\text { Social impact assessment and } \\
\text { public participation in China } \\
\text { (Tang et al., 2008) }\end{array}$ & $\begin{array}{l}\text { Assessment of social impacts and participatory planning in China have been forgotten not only in en- } \\
\text { vironmental laws but also in all institutions related to state-society relations, ruling socialist ideology, } \\
\text { and traditional Chinese culture. }\end{array}$ \\
\hline $\begin{array}{l}\text { Assessing the social impacts } \\
\text { of extensive resources used } \\
\text { activities (Lockie et al., 2009) }\end{array}$ & $\begin{array}{l}\text { Destruction of resources is to reduce the costs of dealing with and confronting resource users. This } \\
\text { has resulted in negative social effects, especially for vulnerable groups and low-income industries. }\end{array}$ \\
\hline $\begin{array}{l}\text { Social impact assessment in } \\
\text { mining projects in Northern } \\
\text { Finland (Suopajärvi, 2013) }\end{array}$ & $\begin{array}{l}\text { International standards and guidelines are not considered seriously in these projects; for example, } \\
\text { elderly people are very much concerned about these standards, but no attempt has been made to } \\
\text { identify these and other vulnerable groups in the projects. }\end{array}$ \\
\hline $\begin{array}{l}\text { Urban environmental as- } \\
\text { sessment and social impact } \\
\text { assessment of tourism } \\
\text { development policy (Thanvisit- } \\
\text { thpon, 2016) }\end{array}$ & $\begin{array}{l}\text { The social impact of tourism development policy has been unsuccessful due to lack of joyful activities } \\
\text { and the prohibition of local people from participating in business activities. These problems are due } \\
\text { to lack of leadership and coherence in society. }\end{array}$ \\
\hline $\begin{array}{l}\text { Socioeconomic and environ- } \\
\text { mental impact analysis of } \\
\text { Kardeh Mashhad and Bidwas } \\
\text { Esfarayn dams (Shayan et al., } \\
\text { 2009) }\end{array}$ & $\begin{array}{l}\text { The social effects were transient and as part of the research and concluded that the social effects of } \\
\text { dams were negative, for some of its reasons: the mere look at engineering, ignoring the customary } \\
\text { and civil laws governing river water resources, neglecting knowledge and native management, an } \\
\text { extensive bureaucracy of state government over structures, and so on. }\end{array}$ \\
\hline $\begin{array}{l}\text { Assessing the social and } \\
\text { environmental impacts on the } \\
\text { construction and develop- } \\
\text { ment of the Fereydunkenar } \\
\text { Port on the local community } \\
\text { (Salehi et al., 2013) }\end{array}$ & $\begin{array}{l}\text { Five indicators of employment creation, noise pollution, impact on the local economy, tourism rates } \\
\text { and land prices were reviewed, and the results revealed that Fereydunkenar port has not been eco- } \\
\text { nomically able to create a great job opportunity for the region and reduce the unemployment rate } \\
\text { in the region, also it has not polluted the port, and had no effect on the arrival of the tourists in the } \\
\text { area. But it has raised the price of land in the region. }\end{array}$ \\
\hline $\begin{array}{l}\text { Assessment of social impact } \\
\text { of Oil and Gas Industry Devel- } \\
\text { opment in Bushehr Province: } \\
\text { Case Study: South Pars (Abed- } \\
\text { izadeh, 2013) }\end{array}$ & $\begin{array}{l}\text { The implementation of the South Pars project has increased the citizens' satisfaction and welfare } \\
\text { services in the local community. But it also increases the problems and social harms in the local com- } \\
\text { munity. Overall, the research findings showed that the impact of the South Pars project on the quality } \\
\text { of life in the local community has decreased. }\end{array}$ \\
\hline $\begin{array}{l}\text { Assessment of social impacts } \\
\text { on the Mehr Ardabil housing } \\
\text { project (Fathi, 2014) }\end{array}$ & $\begin{array}{l}\text { The construction of the residential complex of the Mehr Ardebil housing project have had positive } \\
\text { effects on families and their mental and psychological health. }\end{array}$ \\
\hline
\end{tabular}

- JSRD

There are many definitions for social impact assessment. According to Vanclay, social impact assessment involves processes for analyzing, monitoring, managing unintended, positive and negative social consequences, planned interventions (policies, programs, plans, and projects) and any social change process resulting from these interventions. A way in which the human and biological environment has become more sustainable and fairer (Vanclay, 2006:10). Also, social impact assessment is defined as the process of identifying the future outcomes of a practical or suggestive action that is relevant to individuals, organizations, and large-scale social systems (Karami et al., 2017:26; Becker, 2001:312).

Western and Lynch argued that social impact analysis is the assessment of various policies. According to them, every policy process involves four steps: 1 . formulating different policies and replacing each other, 2. selecting a policy for implementation, 3 . implementing a selected policy, and 4. assessment and reforming. The social impact assessment is a tool for the second stage, although it is also used in the fourth stage (Fazeli, 2010:59-60). The definition of the interagency committee identifies the strategies and principles for assessing the social consequences of many aspects of the concept: an attempt to assess the social consequences by specific measures and policies, including new programs and policies, and the implementation of specific government programs, including the allocation of large amounts of land to desperate natural resource projects is called "Social Impact Assessment".

Another version of the report published by the Committee states that the social impact of any public and private actions is the way of life, work, communication, satisfying the needs, and overcoming the problems 
Table 2. Specifications of community size and sample

\begin{tabular}{|c|c|c|c|c|c|}
\hline \multirow{2}{*}{ Name } & \multicolumn{2}{|c|}{ Community Size 2011} & \multicolumn{3}{|c|}{ Sample Size } \\
\hline & Household & Population & $5 \%$ & Added Accuracy & Final Volume \\
\hline Parkandabad & 103 & 359 & 5.15 & 4.85 & 10 \\
\hline Khin-e Arab & 375 & 1275 & 18.75 & 1.25 & 19 \\
\hline Kalatehnuri & 83 & 253 & 4.15 & 5.85 & 10 \\
\hline Arvand & 72 & 220 & 3.6 & 6.4 & 10 \\
\hline Frizi & 404 & 1376 & 20.2 & -0.2 & 20 \\
\hline Kowshmahdi & 1010 & 3673 & 50.5 & 0.5 & 51 \\
\hline Total & 2047 & 7156 & 102.35 & 18.65 & 120 \\
\hline
\end{tabular}

(Roch, 2008:10; Fazeli, 2010:59; Salehi et al., 2013:43). The social assessment also helps find social risks and counteract the negative outcomes of projects (Dreyer, Renn, Cope, \& Frewer, 2010:1626). Finsterbusch has a look at the contexts of social impact assessment and lists a full list of the contexts of its application (Fazeli, 2010:223-224). These contexts are:

1. Demographic changes: An estimate of population growth or decline is important.

2. Changes in employment: The simplest form of change in employment pattern is the increase in the need for labor in the project implementation area. However, projects are not always associated with increasing employment in the long-term or providing permanent employment.

3. Spatial displacement and change in the residence of the individuals: often, major projects cause changes in the quality and physical construction of communities.

4. Disturbing the neighborhood structure of people's livelihoods: development projects have the ability to disrupt links and social connections.

5. Noise effects: often implementing development projects create a disturbing noise that affects the quality of social life.

6. Aesthetic effects: Although the aesthetic effects of development projects is not paid much attention, however, any change in the aesthetic dimensions of the environment affects the morale and life of individuals.
7. Changes in people's access to facilities: Development projects often affect the structure of people's access to the necessary facilities for life.

8. Effects on leisure and recreation facilities: Leisure facilities are affected by their development projects and their future function. Considering the importance of this opportunity and the economic profitability that can be achieved through tourist attraction, its degradation or reduction of service has consequences for society.

9. Health and safety: This is one of the most important consequences of development projects, which should be taken seriously.

10. Checking the people's reactions: Local people affected by the project often respond to changes in their living environment.

11. Impact on local communities: Decisions taken during the project, such as land allocation to specific users, can cause local communities to grow or decay.

12. Changes in land use: All projects, in particular, large-scale projects that require a lot of lands, will change the pattern of land use.

It should be noted that the 12 Finsterbusch indicators are applicable to projects that are ongoing all day and night. These projects, due to their high economic, sociocultural and environmental impacts, affect local communities (Salehi et al., 2013:42-45). Therefore, based on the Parkandabad sewage treatment plant characteristics, 12 Finsterbusch indicators were selected and studied in this research. In this regard, the main question of the re- 


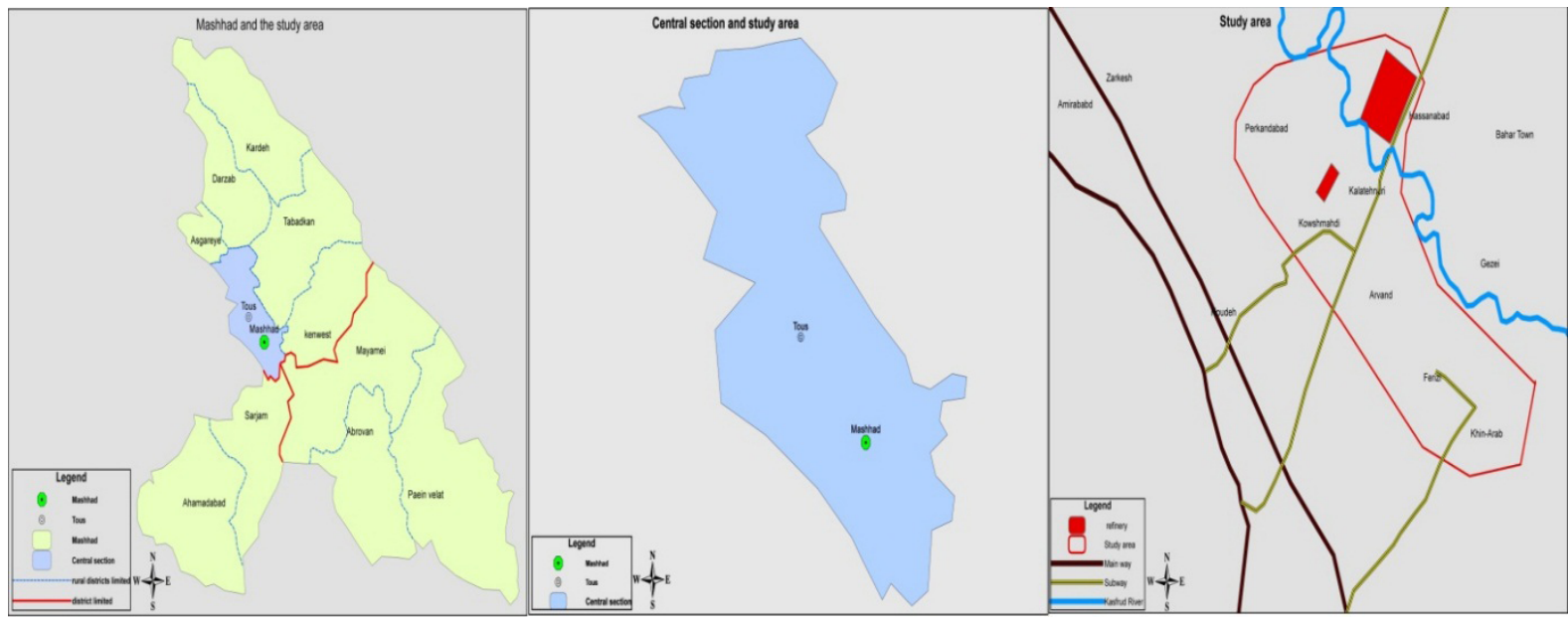

Figure 1. Location of the studied area

search was as follows: What was the effect of Parkandabad sewage treatment plant on each of the 12 indices?

\section{Methodology}

According to the nature of the subject and the question, the research method is descriptive-analytical. Data were collected by library and field studies. Field information was collected through a questionnaire. Then, single sam- ple $t$ test was carried out by setting criterion score 3 as the acceptable standard at a significant level smaller than 0.05 .

The study area consists of six villages (Parkandabad, Kowshmahdi, Kalatehnuri, Frizi, Arvand, and Khin-e Arab) from the central part of Tous District of Mashhad City (Figure 1) with a total population of 7156 people and 2047 households (Statistics Center of Iran, 2011). Of these, $5 \%$ of households, i.e. 102 households were

Table 3. Indicators and research items

\begin{tabular}{|c|c|}
\hline Indicators & Items \\
\hline Demographic changes & $\begin{array}{l}\text { Immigration into the region- Immigration outside the region- Population stabilization of } \\
\text { the region }\end{array}$ \\
\hline Changes in employment & Increasing employment - loss of some jobs in the region \\
\hline $\begin{array}{l}\text { Place displacement and change of life } \\
\text { position of individuals }\end{array}$ & Change of the place of residence - The displacement of the place of employment \\
\hline $\begin{array}{l}\text { Disturbing the structure of the place } \\
\text { where people live }\end{array}$ & Changing the structure of neighborhoods - The transformation of houses \\
\hline Noise effects & Creating annoying noise \\
\hline Aesthetic effects & Creating an unpleasant face in the region- Disrupting the texture of the region \\
\hline Changes in people's access to facilities & $\begin{array}{l}\text { Creating asphalt roads in the region- Disrupting some services such as educational and } \\
\text { recreational services }\end{array}$ \\
\hline Impact on leisure and recreation facilities & $\begin{array}{l}\text { Creating new living facilities such as parks - Reducing leisure facilities and recreation - } \\
\text { Reducing the number of tourist's }\end{array}$ \\
\hline Health and safety & $\begin{array}{l}\text { Threat to drinking water - Toxic gases - Toxins and harmful rodents - Distribution of fine } \\
\text { particles of sewage in the air - Outbreaks of new diseases }\end{array}$ \\
\hline Investigating people's reactions & $\begin{array}{l}\text { Opposition to construction and commissioning- Participation in the creation, Holding pub- } \\
\text { lic gatherings- Talk with project managers- Differences in wastewater consumption among } \\
\text { people - Change in social relations of people }\end{array}$ \\
\hline Impact on local communities & $\begin{array}{c}\text { Misuse (like rent, etc.) - Limiting people's access to natural resources - Conflicts with } \\
\text { religious values of the people }\end{array}$ \\
\hline Changes in land-use & $\begin{array}{l}\text { Land-use change - Increase of greenery- Land price decrease - Reducing land purchase } \\
\text { tendency- Desire to use wastewater due to drought- Increase production efficiency- } \\
\text { Landscaping the water without water- Change in the number of livestock - Increased } \\
\text { willingness to invest - Reduce water consumption from the well- Change the type of } \\
\text { cultivation-Reduce product quality }\end{array}$ \\
\hline
\end{tabular}


Table 4. Reliability of research variables

\begin{tabular}{ccccc}
\hline & Scale Mean if Item & Item-Total Statistics & & \\
\hline Deleted & $\begin{array}{c}\text { Scale Variance if Item } \\
\text { Deleted }\end{array}$ & $\begin{array}{c}\text { Corrected Item-Total } \\
\text { Correlation }\end{array}$ & $\begin{array}{c}\text { Cronbach's } \boldsymbol{\alpha} \text { if Item } \\
\text { Deleted }\end{array}$ \\
\hline Population & 42.0453 & 18.909 & 0.682 & 0.730 \\
\hline Employment & 42.1981 & 21.067 & 0.110 & 0.783 \\
\hline Movement & 41.1773 & 16.550 & 0.580 & 0.727 \\
\hline Structure & 42.0273 & 18.210 & 0.653 & 0.725 \\
\hline Voice & 42.6439 & 20.085 & 0.191 & 0.779 \\
\hline Aesthetic & 43.8939 & 19.955 & 0.186 & 0.782 \\
\hline Facilities & 42.7481 & 20.002 & 0.273 & 0.765 \\
\hline Leisure & 41.5886 & 17.849 & 0.592 & 0.728 \\
\hline Health & 44.2523 & 21.258 & 0.122 & 0.777 \\
\hline Reaction & 41.9744 & 17.709 & 0.692 & 0.719 \\
\hline Communities & 42.3772 & 18.772 & 0.586 & 0.734 \\
\hline Land use & 43.1318 & 20.243 & 0.647 & 0.745 \\
\hline Average & & & & 0.750 \\
\hline
\end{tabular}

selected as primary sample size. However, in villages where $5 \%$ of the society was less than 10 households; the sample size was 10 to increase the accuracy of the work, so finally 120 households were selected as the total sample size. Then, a simple randomized questionnaire was distributed among them (Table 2).

\section{Variables}

Social impacts of Parkandabad Refinery on the lives of people based on 12 indicators and 43 items according to the research objectives were assessed (Table 3 ).

\section{Reliability of variables}

The Cronbach's $\alpha$ coefficient was used to measure the reliability of the indices. The range of Cronbach's $\alpha$ is between 0 and +1 . If the alpha value is greater than 0.7 , the reliability is good and if it is between 0.5 and 0.7 , the reliability is moderate and if less than 0.5 , then the questionnaire is unreliable. After calculation, the average total reliability of the research structures was found as 0.75 and the reliability of all variables was less than 0.7 . Therefore, research variables have high reliability (Table 4 ).

\section{Findings}

According to Table 5, the health and safety index with an average score of 2.11 and among its items, the smell of gases with the average score of 1.5 has the worst situation, and the aesthetic index with an average score of 2.47 is in the next place. It means that these indicators are lower than the acceptable average score (criterion score of 3 ) and should be considered within this context, because they are directly related to the body (health and safety) and mental (aesthetic) conditions of humans. Second, there are a number of indicators (noise, facilities, communities, and utilization) that are acceptable but their status should be improved. Third, several indicators (population, employment, structure, leisure, and reaction) apparently have a relatively favorable situation, but this situation is mainly due to economic poverty that exists among the people of the region. Fourth, the favorable situation of the spatial displacement index and the change in the place of people's residence with an average score of 5.19 seem to indicate a good living condition within the area, with few people willing to move, but in fact, this is not the case and the index has a high standard deviation. In other words, inappropriate 
financial conditions have prevented the population from being displaced.

According to Table 6, the studied villages were ranked for each of the 12 indices. Regarding the demographic change index, Kalatehnuri got the worst and Arvand the best situation. With regard to the index of changes in the employment rate, Kowshmahdi got the most unfavorable condition and Khin-e Arab the most favorable one. Considering the displacement index and the change in the place of residence, Kalatehnuri took the most unsuitable condition and Parkandabad got the most suitable one. With regard to change in local people's residence, Frizi showed the worst change and Khin-e Arab the best.

Table 5. One-sample $t$ test analysis and ranking of indices and items (1: the worst case and 43: the best situation)

\begin{tabular}{|c|c|c|c|c|c|c|c|c|}
\hline \multicolumn{9}{|c|}{ Criterion Score 3} \\
\hline Indicator & Item & Number & Mean & SD & $\mathbf{t}$ & Significance & $\begin{array}{l}\text { Index } \\
\text { Rating }\end{array}$ & $\begin{array}{l}\text { Item } \\
\text { Rating }\end{array}$ \\
\hline \multirow{4}{*}{$\begin{array}{l}\text { Demographic } \\
\text { changes }\end{array}$} & Immigration into the region & 120 & 5.3167 & 1.06891 & 23.742 & 0.000 & \multirow{4}{*}{8} & 42 \\
\hline & $\begin{array}{l}\text { Immigration outside the } \\
\text { region }\end{array}$ & 120 & 3.4417 & 0.49867 & 9.702 & 0.000 & & 19 \\
\hline & $\begin{array}{l}\text { Population stabilization of } \\
\text { the region }\end{array}$ & 120 & 4.2083 & 0.98643 & 13.419 & 0.000 & & 25 \\
\hline & Average & 120 & 4.3236 & 0.5387 & 26.915 & 0.000 & & $*$ \\
\hline \multirow{3}{*}{$\begin{array}{l}\text { Changes in } \\
\text { employment }\end{array}$} & Increasing employment & 120 & 4.8333 & 1.06379 & 18.879 & 0.000 & \multirow{3}{*}{7} & 31 \\
\hline & $\begin{array}{l}\text { Loss of some jobs in the } \\
\text { region }\end{array}$ & 120 & 3.5083 & 1.12269 & 4.96 & 0.000 & & 20 \\
\hline & Average & 120 & 4.1708 & 0.75453 & 16.999 & 0.000 & & $*$ \\
\hline \multirow{3}{*}{$\begin{array}{l}\text { Place displace- } \\
\text { ment and } \\
\text { change of place } \\
\text { of life of indi- } \\
\text { viduals }\end{array}$} & $\begin{array}{l}\text { Change of the place of } \\
\text { residence }\end{array}$ & 120 & 5.2333 & 1.05108 & 23.276 & 0.000 & \multirow{3}{*}{12} & 40 \\
\hline & $\begin{array}{l}\text { The displacement of the } \\
\text { place of employment }\end{array}$ & 120 & 5.15 & 1.08194 & 21.768 & 0.000 & & 36 \\
\hline & Average & 120 & 5.1917 & 1.01911 & 23.558 & 0.000 & & $*$ \\
\hline \multirow{3}{*}{$\begin{array}{l}\text { Disturbing the } \\
\text { structure on } \\
\text { the place where } \\
\text { people live }\end{array}$} & $\begin{array}{l}\text { Changing the structure of } \\
\text { neighborhoods }\end{array}$ & 120 & 3.5167 & 0.54976 & 20.295 & 0.000 & \multirow{3}{*}{9} & 21 \\
\hline & $\begin{array}{l}\text { The transformation of } \\
\text { houses }\end{array}$ & 120 & 5.1667 & 1.1547 & 20.55 & 0.000 & & 38 \\
\hline & Average & 120 & 4.3417 & 0.67045 & 21.921 & 0.000 & & $*$ \\
\hline Noise effects & Creating annoying noise & 120 & 3.7250 & 0.88842 & 8.939 & 0.000 & 5 & 22 \\
\hline \multirow{3}{*}{ Aesthetic effects } & $\begin{array}{l}\text { Creating an unpleasant face } \\
\text { in the region }\end{array}$ & 120 & 2.1583 & 1.3347 & -6.908 & 0.000 & \multirow{3}{*}{2} & 9 \\
\hline & $\begin{array}{l}\text { Disrupting the texture of } \\
\text { the region }\end{array}$ & 120 & 2.7917 & 1.05237 & -2.169 & 0.032 & & 13 \\
\hline & Average & 120 & 2.4750 & 0.93900 & -6.125 & 0.000 & & $*$ \\
\hline \multirow{3}{*}{$\begin{array}{l}\text { Changes in } \\
\text { people's access } \\
\text { to facilities }\end{array}$} & $\begin{array}{l}\text { Creating asphalt roads in } \\
\text { the region }\end{array}$ & 120 & 3.1083 & 0.9148 & 1.297 & 0.197 & \multirow{3}{*}{4} & 14 \\
\hline & $\begin{array}{l}\text { Disrupting some services } \\
\text { such as educational and } \\
\text { recreational services }\end{array}$ & 120 & 4.133 & 1.1371 & 10.918 & 0.000 & & 24 \\
\hline & Average & 120 & 3.6208 & 0.75034 & 9.064 & 0.000 & & $*$ \\
\hline \multirow{4}{*}{$\begin{array}{l}\text { Impact on } \\
\text { leisure and rec- } \\
\text { reation facilities }\end{array}$} & $\begin{array}{l}\text { Creating new living facilities } \\
\text { such as parks }\end{array}$ & 120 & 4.2583 & 1.04918 & 13.138 & 0.000 & \multirow{4}{*}{11} & 27 \\
\hline & $\begin{array}{l}\text { Reducing leisure facilities } \\
\text { and recreation }\end{array}$ & 120 & 5.0667 & 1.1356 & 19.936 & 0.000 & & 35 \\
\hline & $\begin{array}{l}\text { Reducing the number of } \\
\text { tourists }\end{array}$ & 120 & 5.0167 & 1.1226 & 19.679 & 0.000 & & 34 \\
\hline & Average & 120 & 4.7803 & .78556 & 24.826 & 0.000 & & $*$ \\
\hline
\end{tabular}




\begin{tabular}{|c|c|c|c|c|c|c|c|c|}
\hline \multicolumn{9}{|c|}{ Criterion Score 3} \\
\hline Indicator & Item & Number & Mean & SD & $\mathbf{t}$ & Significance & $\begin{array}{l}\text { Index } \\
\text { Rating }\end{array}$ & $\begin{array}{l}\text { Item } \\
\text { Rating }\end{array}$ \\
\hline \multirow{6}{*}{$\begin{array}{l}\text { Health and } \\
\text { safety }\end{array}$} & Threat to drinking water & 120 & 1.8833 & 1.0223 & -11.966 & 0.000 & \multirow{6}{*}{1} & 6 \\
\hline & Toxic gases & 120 & 1.5 & 0.6736 & -24.393 & 0.000 & & 1 \\
\hline & Toxins and harmful rodents & 120 & 1.733 & 0.7749 & -17.905 & 0.000 & & 4 \\
\hline & $\begin{array}{l}\text { Distribution of fine particles } \\
\text { of sewage in the air }\end{array}$ & 120 & 2.05 & 1.11408 & -9.341 & 0.000 & & 7 \\
\hline & Outbreaks of new diseases & 120 & 3.4167 & 1.1637 & 3.922 & 0.000 & & 18 \\
\hline & Average & 120 & 2.1167 & 0.64278 & -15.054 & 0.000 & & $*$ \\
\hline \multirow{7}{*}{$\begin{array}{l}\text { Investigating } \\
\text { people's reac- } \\
\text { tions }\end{array}$} & $\begin{array}{l}\text { Opposition to construction } \\
\text { and commissioning }\end{array}$ & 120 & 5.2 & 1.10461 & 21.817 & 0.000 & \multirow{7}{*}{10} & 39 \\
\hline & Participation in the creation & 120 & 3.1167 & 0.89989 & 1.42 & 0.158 & & 15 \\
\hline & Holding public gatherings & 120 & 4.9583 & 1.1767 & 18.23 & 0.000 & & 32 \\
\hline & Talk with project managers & 120 & 5.1667 & 1.1021 & 21.526 & 0.000 & & 37 \\
\hline & $\begin{array}{l}\text { Differences in wastewa- } \\
\text { ter consumption among } \\
\text { people }\end{array}$ & 120 & 2.6583 & 1.05716 & -3.54 & 0.001 & & 11 \\
\hline & $\begin{array}{l}\text { Change in social relations } \\
\text { of people }\end{array}$ & 120 & 5.2667 & 1.02681 & 24.182 & 0.000 & & 41 \\
\hline & Average & 120 & 4.3945 & 0.71679 & 21.306 & 0.000 & & $*$ \\
\hline \multirow{4}{*}{$\begin{array}{l}\text { Impact on local } \\
\text { communities }\end{array}$} & Misuse (like rent, etc.) & 120 & 4.775 & 1.04087 & 18.681 & 0.000 & \multirow{4}{*}{6} & 30 \\
\hline & $\begin{array}{l}\text { Limiting people's access to } \\
\text { natural resources }\end{array}$ & 120 & 4.975 & 1.1111 & 19.471 & 0.000 & & 33 \\
\hline & $\begin{array}{l}\text { Conflicts with religious } \\
\text { values among the people }\end{array}$ & 120 & 2.225 & 1.3501 & -6.288 & 0.000 & & 10 \\
\hline & Average & 120 & 3.9918 & 0.63429 & 17.128 & 0.000 & & $*$ \\
\hline \multirow{13}{*}{$\begin{array}{l}\text { Changes in } \\
\text { land- use }\end{array}$} & Land-use change & 120 & 2.75 & 1.1171 & -2.452 & 0.016 & \multirow{13}{*}{3} & 12 \\
\hline & Increase of greenery & 120 & 4.25 & 0.9979 & 13.722 & 0.000 & & 26 \\
\hline & Land price decrease & 120 & 1.7583 & 0.89814 & -15.144 & 0.000 & & 5 \\
\hline & $\begin{array}{l}\text { Reducing land purchases } \\
\text { tendency }\end{array}$ & 120 & 1.5083 & 0.71 & -23.014 & 0.000 & & 2 \\
\hline & $\begin{array}{l}\text { Desire to use wastewater } \\
\text { due to drought }\end{array}$ & 120 & 3.3667 & 1.1371 & 3.532 & 0.001 & & 17 \\
\hline & $\begin{array}{l}\text { Increase production ef- } \\
\text { ficiency }\end{array}$ & 120 & 2.1 & 1.1031 & -8.938 & 0.000 & & 8 \\
\hline & $\begin{array}{l}\text { Landscaping the water } \\
\text { without water }\end{array}$ & 120 & 2.833 & 0.9643 & 9.466 & 0.000 & & 23 \\
\hline & $\begin{array}{l}\text { Change in the number of } \\
\text { livestock }\end{array}$ & 120 & 4.2667 & 0.9765 & 14.21 & 0.000 & & 28 \\
\hline & $\begin{array}{c}\text { Increased willingness to } \\
\text { invest }\end{array}$ & 120 & 5.3583 & 0.977 & 26.441 & 0.000 & & 43 \\
\hline & $\begin{array}{l}\text { Reduce water consumption } \\
\text { from the well }\end{array}$ & 120 & 4.7583 & 1.0532 & 18.289 & 0.000 & & 29 \\
\hline & $\begin{array}{c}\text { Change the type of cultiva- } \\
\text { tion }\end{array}$ & 120 & 3.1667 & 0.8919 & 2.047 & 0.043 & & 16 \\
\hline & Reduce product quality & 120 & 1.733 & 0.764 & -18.161 & 0.000 & & 3 \\
\hline & Average & 120 & 3.2371 & 0.34872 & 7.448 & 0.000 & & $*$ \\
\hline
\end{tabular}


Table 6. One-sample t test analysis and village ranking based on each index independently

\begin{tabular}{|c|c|c|c|c|c|c|c|c|c|c|c|}
\hline \multicolumn{12}{|c|}{ Criterion Score 3} \\
\hline $\begin{array}{l}\text { Village } \\
\text { Name }\end{array}$ & Mean & SD & $\mathbf{t}$ & Sig. & Rank & $\begin{array}{l}\text { Village } \\
\text { Name }\end{array}$ & Mean & SD & $\mathbf{t}$ & Sig. & Rank \\
\hline \multicolumn{6}{|c|}{ Population } & \multicolumn{6}{|c|}{ Facilities } \\
\hline Parkandabad & 4.2670 & 0.34471 & 11.623 & 0.000 & 4 & Parkandabad & 3.2500 & 0.88976 & 0.889 & 0.397 & 6 \\
\hline Khin-e Arab & 4.2463 & 0.63754 & 8.521 & 0.000 & 5 & Khin-e Arab & 3.4737 & 0.92005 & 2.244 & 0.038 & 5 \\
\hline Kalatehnuri & 4.5680 & 0.35389 & 14.011 & 0.000 & 1 & Kalatehnuri & 3.9000 & 0.69921 & 4.070 & 0.003 & 1 \\
\hline Arvand & 4.1680 & 0.67257 & 5.492 & 0.000 & 6 & Arvand & 3.5500 & 0.64334 & 2.703 & 0.024 & 4 \\
\hline Frizi & 4.4015 & 0.54807 & 11.436 & 0.000 & 2 & Frizi & 3.8500 & 0.70897 & 5.362 & 0.000 & 2 \\
\hline Kowshmahdi & 4.3155 & 0.53166 & 17.670 & 0.000 & 3 & Kowshmahdi & 3.6176 & 0.68256 & 6.462 & 0.000 & 3 \\
\hline \multicolumn{6}{|c|}{ Employment } & \multicolumn{6}{|c|}{ Leisure } \\
\hline Parkandabad & 3.9500 & 0.68516 & 4.385 & 0.002 & 5 & Parkandabad & 4.9340 & 0.49302 & 12.405 & 0.000 & 1 \\
\hline Khin-e Arab & 3.7895 & 1.04504 & 3.293 & 0.004 & 6 & Khin-e Arab & 4.7895 & 0.80982 & 9.632 & 0.000 & 4 \\
\hline Kalatehnuri & 4.2000 & 0.88819 & 4.272 & 0.002 & 3 & Kalatehnuri & 4.8000 & 0.83622 & 6.807 & 0.000 & 3 \\
\hline Arvand & 4.0000 & 0.57735 & 5.477 & 0.000 & 4 & Arvand & 4.7660 & 0.88856 & 6.285 & 0.000 & 5 \\
\hline Frizi & 4.2750 & 0.67814 & 8.408 & 0.000 & 2 & Frizi & 4.8000 & 0.83352 & 9.658 & 0.000 & 2 \\
\hline Kowshmahdi & 4.3431 & 0.62841 & 15.264 & 0.000 & 1 & Kowshmahdi & 4.7380 & 0.80623 & 15.395 & 0.000 & 6 \\
\hline \multicolumn{6}{|c|}{ Movement } & \multicolumn{6}{|c|}{ Health } \\
\hline Parkandabad & 5.0500 & 0.89598 & 7.235 & .0000 & 6 & Parkandabad & 1.9600 & 0.50596 & -6.500 & 0.000 & 6 \\
\hline Khin-e Arab & 5.0526 & 1.11673 & 8.012 & 0.000 & 5 & Khin-e Arab & 2.0947 & 0.66789 & -5.908 & 0.000 & 5 \\
\hline Kalatehnuri & 5.4500 & 0.68516 & 11.308 & 0.000 & 1 & Kalatehnuri & 2.2600 & 0.72449 & -3.230 & 0.010 & 1 \\
\hline Arvand & 5.2000 & 1.03280 & 6.736 & 0.000 & 4 & Arvand & 2.1000 & 0.80139 & -3.551 & 0.006 & 4 \\
\hline Frizi & 5.2000 & 0.99207 & 9.917 & 0.000 & 3 & Frizi & 2.1800 & 0.76475 & -4.795 & 0.000 & 2 \\
\hline Kowshmahdi & 5.2157 & 1.09661 & 14.429 & 0.000 & 2 & Kowshmahdi & 2.1059 & 0.57738 & -11.059 & 0.000 & 3 \\
\hline \multicolumn{6}{|c|}{ Structure } & \multicolumn{6}{|c|}{ Reaction } \\
\hline Parkandabad & 4.2500 & 0.48591 & 8.135 & 0.000 & 5 & Parkandabad & 4.0490 & 0.64314 & 5.158 & 0.001 & 6 \\
\hline Khin-e Arab & 4.1842 & 0.69143 & 7.466 & 0.000 & 6 & Khin-e Arab & 4.2195 & 0.68518 & 7.758 & 0.000 & 5 \\
\hline Kalatehnuri & 4.4000 & 0.77460 & 5.715 & 0.000 & 2 & Kalatehnuri & 4.8000 & 0.44860 & 12.689 & 0.000 & 1 \\
\hline Arvand & 4.3500 & 0.62583 & 6.821 & 0.000 & 4 & Arvand & 4.3990 & 0.72820 & 6.075 & 0.000 & 3 \\
\hline Frizi & 4.4500 & 0.62618 & 10.356 & 0.000 & 1 & Frizi & 4.5750 & 0.77160 & 9.129 & 0.000 & 2 \\
\hline Kowshmahdi & 4.3627 & 0.71469 & 13.617 & 0.000 & 3 & Kowshmahdi & 4.3763 & 0.73502 & 13.372 & 0.000 & 4 \\
\hline \multicolumn{6}{|c|}{ Sound } & \multicolumn{6}{|c|}{ Communities } \\
\hline Parkandabad & 3.8000 & 1.03280 & 2.449 & 0.037 & 2 & Parkandabad & 3.8000 & 0.58984 & 4.289 & 0.002 & 5 \\
\hline
\end{tabular}




\begin{tabular}{cccccccccccc}
\hline \multicolumn{1}{c}{ Village } & Mean & SD & t & Sig. & Rank & $\begin{array}{c}\text { Village } \\
\text { Name }\end{array}$ & Mean & SD & t & Sig. & Rank \\
\hline Khin-e Arab & 3.7368 & 0.99119 & 3.240 & 0.005 & 3 & Khin-e Arab & 3.7537 & 0.74497 & 4.410 & 0.000 & 6 \\
\hline Kalatehnuri & 3.5000 & 0.52705 & 3.000 & 0.015 & 5 & Kalatehnuri & 3.9670 & 0.53267 & 5.741 & 0.000 & 4 \\
\hline Arvand & 3.5000 & 0.97183 & 1.627 & 0.138 & 6 & Arvand & 4.0000 & 0.76836 & 4.116 & 0.003 & 3 \\
\hline Frizi & 3.6500 & 0.81273 & 3.577 & 0.002 & 4 & Frizi & 4.1505 & 0.59670 & 8.623 & 0.000 & 1 \\
\hline Kowshmahdi & 3.8235 & 0.91007 & 6.462 & 0.000 & 1 & Kowshmahdi & 4.0590 & 0.59897 & 12.627 & 0.000 & 2 \\
\hline Parkandabad & 2.0500 & 0.76194 & -3.943 & 0.003 & 3 & Parkandabad & 3.1740 & 0.31038 & 1.773 & 0.110 & 5 \\
\hline Khin-e Arab & 2.4737 & 1.03379 & -2.219 & 0.040 & 2 & Khin-e Arab & 3.1795 & 0.37676 & 2.076 & 0.052 & 4 \\
\hline Kalatehnuri & 2.4500 & 0.79757 & -2.181 & 0.057 & 5 & Kalatehnuri & 3.3740 & 0.30660 & 3.857 & 0.004 & 1 \\
\hline Arvand & 2.4500 & 1.16548 & -1.492 & 0.170 & 6 & Arvand & 3.1400 & 0.35771 & 1.238 & 0.247 & 6 \\
\hline Frizi & 2.5750 & 1.09153 & -1.741 & 0.098 & 4 & Frizi & 3.3040 & 0.37345 & 3.640 & 0.002 & 2 \\
\hline Kowshmahdi & 2.5294 & 0.86840 & -3.870 & 0.000 & 1 & Kowshmahdi & 3.2369 & 0.34430 & 4.913 & 0.000 & 3 \\
\hline
\end{tabular}

In the context of the noise effect, Koushmehdi has the most unfavorable condition, and Arvand the most desirable one. With respect to aesthetic effect, Koushmehd had the worst condition and Arvand had the most suited status. In the case of the index of changes in access for the population, Kalatehnuri got the worst condition and Parkandabad got the best one. Regarding the impact index on leisure facilities and recreational facilities, the most unsuitable case belonged to Koushmehdi and the most suitable to Parkandabad. In the context of health and safety index, the worst is Kalatehnuri and Parkandabad is the best. With regard to the index of the reactions among the public, the most unsuitable reactions was seen in Kalatehnuri and the most suitable in Parkandabad. Regarding the index of the impact upon local communities, Frizi had the worst condition and Khin-e Arab the best condition. Finally regarding the land-use change indicators, the most unsuitable case was Kalatehnuri and the most suitable one was Arvand.

Table 7. Ranking of the villages based on the total score of indices

\begin{tabular}{|c|c|c|c|c|c|c|c|c|c|c|c|c|c|c|}
\hline Name & 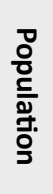 & $\begin{array}{l}\text { m } \\
\frac{3}{3} \\
\frac{0}{0} \\
\frac{1}{3} \\
3 \\
\frac{0}{2} \\
\frac{1}{+}\end{array}$ & 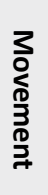 & 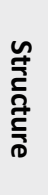 & 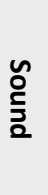 & 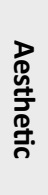 & 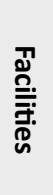 & $\frac{\sqrt{D}}{\frac{5}{5}}$ & $\begin{array}{l}\frac{T}{\mathbb{D}} \\
\frac{D}{\mathbf{D}}\end{array}$ & 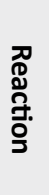 & 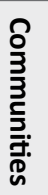 & $\frac{\sqrt{0}}{\underline{2}}$ & $\begin{array}{l}\frac{1}{0} \\
\frac{d}{\tilde{D}} \\
\frac{0}{D}\end{array}$ & $\begin{array}{l}\text { 꼼 } \\
\text { 긋 }\end{array}$ \\
\hline Parkandabad & 4 & 5 & 6 & 5 & 2 & 3 & 6 & 1 & 6 & 6 & 5 & 5 & 54 & 5 \\
\hline Khin-e Arab & 5 & 6 & 5 & 6 & 3 & 2 & 5 & 4 & 5 & 5 & 6 & 4 & 56 & 6 \\
\hline Kalatehnuri & 1 & 3 & 1 & 2 & 5 & 5 & 1 & 3 & 1 & 1 & 4 & 1 & 28 & 2 \\
\hline Arvand & 6 & 4 & 4 & 4 & 6 & 6 & 4 & 5 & 4 & 3 & 3 & 6 & 51 & 3 \\
\hline Frizi & 2 & 2 & 3 & 1 & 4 & 4 & 2 & 2 & 2 & 2 & 1 & 2 & 27 & 1 \\
\hline Kowshmahdi & 3 & 1 & 2 & 3 & 1 & 1 & 3 & 6 & 3 & 4 & 2 & 3 & 32 & 3 \\
\hline
\end{tabular}


According to Table 6 and 7, villages can be ranked based on the total score obtained from the indices. Accordingly, Farisian village with a score of 27 and the first rank has the worst position in terms of twelve indices, and Khin-e Arab village with the score of 56 is in the sixth position and has the best status.

\section{Discussion}

Our study results, in most cases, were consistent with the results of previous investigations. Although development projects are designed and implemented to improve the quality and quantity of local communities, they may not have satisfactory results because of their social impacts. In Suopajärvi (2013) study to evaluate the social impact of mining projects in Northern Flanders, it was found that international standards and guidelines have not been taken into account, also the vulnerable groups and individuals have been overlooked in these projects. These results are consistent with the results of the current research. In another study by Salehi et al. (2013) who assessed the social and environmental impacts on the construction and development of the Fereydunkenar port on the local community, it was found that Fereydunkenar port could not have created the expected job opportunities for the region or reduce the unemployment rate. Also, it neither had contaminated the harbor nor had any effect on the arrival of the tourists to the area. However it had raised the price of land in the region. Abedizadeh (2013) in his research assessment about the social impacts on the development of the Oil and Gas industry in Bushehr Province (case study: South Pars) showed that the overall impact of South Pars project on quality of life in the local community was depredating. This result was in agreement with our findings.

Shayan et al. (2009) concluded that societal, economic and environmental impacts of dams in Mashhad and Bidwas Esfarayn were negative, due to some reasons such as considering just the engineering aspect of the project, neglecting local customary laws and regulations over river water resources, overlooking knowledge and indigenous management, dominated bureaucracy of state sovereignty over local authorities, and so on. However based on a study on the assessment of social impacts of the Mehr Ardabil Housing Project (Fathi, 2014), the construction of the residential complex have mental and psychological health impacts different from the findings of the present study. This inconsistency, as already mentioned, may be due to the nature of the problem.

The study results indicate that the health and safety and the aesthetic effects index, which are directly related to the body and the human psyche, are not in desirable conditions within the region. This is due to the outbreak of various types of parasitic, intestinal and respiratory diseases in the area, which requires immediate plans in this regard. The other indicators like noise, facilities, communities and land use are in acceptable condition but their status must be improved. However, other indicators like population, employment, structure, leisure, and reaction, appear to be of relatively favorable status. Actually, this is not the case, and this situation is the cause of various conditions, such as the economic poverty among the local people, which requires more research. Finally, the desirable condition of the place displacement index, which apparently indicates good living conditions within the area, and that few people are willing to move, does not show the real picture as this index had a high standard deviation among respondents; that is, the inappropriate financial status prevent the population from being displaced.

Based on the mentioned issues, the harmful social effects of Parkandabad sewage treatment plant on the studied area should be dealt with at three levels; 1) Immediate planning for resolving the harmful physical (health and safety) and psychological (aesthetic) effects, 2) medium-term planning to deal with the harmful effects of issues such as noise, facilities, communities and land use, and 3) Long-term planning to prevent the harmful effects of population, employment, structure, leisure, reaction indices, and especially the rate of displacement and change of place during the life of individuals. These indicators seem to be desirable, but the truth is behind hidden layers of information, which requires more research in this regard.

\section{Acknowledgements}

This research did not receive any specific grant from funding agencies in the public, commercial, or not-forprofit sectors.

\section{Conflict of Interest}

The authors declared no conflicts of interest.

\section{References}

Abedizadeh, A. (2013). [Social impact assessment of oil and gas industry development in Bushehr Province (Case study: South Pars) (Persian)] [MSc. thesis]. Tehran: Islamic Azad University. 
Alshuwaikhat, H. M. (2005). Strategic environmental assessment can help solve environmental impact assessment failures in developing countries. Environmental Impact Assessment Review, 25(4), 307-17. doi: 10.1016/j.eiar.2004.09.003

Asselin, J., \& Parkins, J. R. (2009). Comparative case study as social impact assessment: possibilities and limitations for anticipating social change in the far north. Social Indicators Research, 94(3), 483-97. doi: 10.1007/s11205-009-9444-7

Basa, K. K. (2007). Social Impact Assessment (A MODULE). Kolkata: Anthropological Survey of India.

Becker, H., \& Wenckley, F. (2008). International guide to the estimation of social consequences [H. Jalili, Persian Trans]. Tehran: Sociologists Publications.

Becker, H. A. (2001). Social impact assessment. European Journal of Operational Research, 128(2), 311-21. doi: 10.1016/s03772217(00)00074-6

Dreyer, M., Renn, O., Cope, S., \& Frewer, L. J. (2010). Including social impact assessment in food safety governance. Food Control, 21(12), 1620-1628. doi: 10.1016/j.foodcont.2009.05.007

Esteves, A. M., Franks, D., \& Vanclay, F. (2012). Social impact assessment: the state of the art. Impact Assessment and Project Appraisal, 30(1), 34-42. doi: 10.1080/14615517.2012.660356

Fathi, M. (2014). [Social impact assessment, Mehr Ardebil Housing Project (Persian)] [MSc. thesis]. Khalkhal: Islamic Azad University

Fazeli, M. (2010). [Social impact assessment (Persian)]. Tehran: Sociologists Publications.

Karami, S., Karami, E., Buys, L., \& Drogemuller, R. (2017). System dynamic simulation: A new method in Social Impact Assessment (SIA). Environmental Impact Assessment Review, 62, 25-34. doi: 10.1016/j.eiar.2016.07.009

Lockie, S., Rockloff, S., Helbers, D., Gorospe-Lockie, M., \& Lawrence, K. (2009). Assessing the social impacts of extensive resource use activities. Journal of Environmental Planning and Management, 52(4), 437-455. doi: 10.1080/09640560902868165

Mehrvaran, B., Ansari, H., Beheshti, A. \& Esmaieli, K. (2015). [investigate the feasibility of using wastewater purication in irrigation due to its environmental impacts (The effluent treatment plants Parkandabad Mashhad) (Persian)]. Iranian Journal of Irrigation and Drainage, 3(9), 447-40.

Mohammadyari, N., Balader, A. (2008). [Evaluation of the performance of mobile biofilm reactor in urban and industrial sewage treatment (Case study: Parkandabad sewage treatment plant in Mashhad) (Persian)]. Water and Wastewater 19(1), 38-46.

Nouri, J., Nabizadeh, R., Younesian, M. \& Novrouzi, H. (2005). [Environmental impact assessment of Hamedan wastewater treatment plant (Persian)]. Paper presented at The Eighth National Conference on Environmental Health, Tehran, Iran, 17-19 November 2005.

Statistics Center of Iran. (2011). [Population and housing census (Persian)]. Tehran: SCI Publication.

Roch, C. (2008). Project impact assessment [H. Chavashian, Persian Trans]. Tehran: Akhtaran.
Salehi, S., Mohammadi, J., Mir Mohammad Tabar Divkolai, S. A., \& Saradipour, A. (2013). [Social and environmental impact assessment of construction and development of Fereidoonkenar port on local community Fereidoonkenar (Persian)]. Environmental Education and Sustainable Development, 1(4), 41-57.

Shayan, H., Javan, J. \& Kadivar, A. (2009). [Analyzing the social, economical and environmental consequences of Kerdeh dam in Mashhad and Bedvaz dam in Esferayen (Persian)]. Journal of Geography and Regional Development Reseach Journal, 13, $19-43$.

Suopajärvi, L. (2013). Social impact assessment in mining projects in Northern Finland: Comparing practice to theory. Environmental Impact Assessment Review, 42, 25-30. doi: 10.1016/j. eiar.2013.04.003

Talebian, S. \& Omarani Majd, A. (2007). [Assessment of social impact of oil and gas industry projects (Persian)]. Human Resources Management in Oil Industry, 1(1), 102-22.

Tang, B., Wong, S., \& Lau, M. C. (2008). Social impact assessment and public participation in China: A case study of land requisition in Guangzhou. Environmental Impact Assessment Review, 28(1), 57-72. doi: 10.1016/j.eiar.2007.03.004

Thanvisitthpon, N. (2016). Urban environmental assessment and social impact assessment of tourism development policy: Thailand's Ayutthaya Historical Park. Tourism Management Perspectives, 18, 1-5. doi: 10.1016/j.tmp.2016.01.006

Vanclay, F. (2002). Conceptualising social impacts. Environmental Impact Assessment Review, 22(3), 183-211. doi: 10.1016/ s0195-9255(01)00105-6

Vanclay, F. (2006). Principles for social impact assessment: A critical comparison between the international and US documents. Environmental Impact Assessment Review, 26(1), 3-14. doi: 10.1016/j.eiar.2005.05.002 